Вісник Дніпропетровського університету. Серія: геологія, географія. 2016. 24 (1), 65-70.

Vìsnik Dnìpropetrovs'kogo unìversitetu. Serîâ geologîâ, geographìâ

Dnipropetrovsk University Bulletin. Series geology, geography. 2016, 24 (1), 65-70.

doi: $10.15421 / 111610$

http://geology-dnu.dp.ua

UDC $502.62(477.63)$

\title{
Scientific results of monitoring objects of geological heritage in Dnipropetrovsk oblast
}

\author{
Manuyk Vol.V., Manuyk Vad.V. \\ Oles Honchar Dnipropetrovsk National University, e-mail: manuk-geo@,mail.ru
}

\begin{abstract}
We studied the peculiarities of the geological structure of Dnipropetrovsk oblast and the extent of its provision with mineral and raw material resources. We defined the connection between the structural-tectonic, lithological-petrographic and geomorphological factors of geological diversity in the territory and the number and condition of geological relics i.e. of geosites. We have shown that the geological relics have a decisive role in the formation of the Nature Reserve Fund of Ukraine and underlined the necessity for monitoring the objects of geological heritage. The article provides a comparative analysis of quantative estimation of the geological heritage of Dnipropetrovsk oblast, which was done using different sources from different years. We emphasize that geological relics can be central objects for geotourism and also highlight their value as the main components of future geoparks. On the basis of monitoring the geological heritage between 2005 and 2015, we have identified potential new geosites, the list of which is published here for the first time. This paper provides a brief geological characteristic of each new geosite, its chronostratigraphic and administrative location. The active part taken by Ukrainian representatives in the work of the European Association for the Conservation of the Geological Heritage (ProGEO), the will to create a European list of geosites and the realization of the necessity of preserving the geological heritage has allowed us to develop and implement for the first time in the history of the movement for preserving the natural environment the course "Monitoring the objects of geological heritage" for students who are studying in the sphere "Earth Sciences". The article describes the determinants of the practical component of the subject and suggests routes for geological field studies for students both with their tutors and independently. Key words: geosite, geological monument, ProGEO, monitoring, geopark, geotourism, Earth Sciences
\end{abstract}

\section{Наукові результати моніторингу об’єктів геологічної спадщини у Дніпропетровській області}

\author{
Манюк Вол.В., Манюк Вад.В.
}

Дніпропетровський національний університет ім. Олеся Гончара, е-mail: manuk-geo@,mail.ru

\begin{abstract}
Досліджені особливостей геологічної будови Дніпропетровської області та ступінь забезпеченості їі мінеральносировинними ресурсами. Встановлено зв'язок між структурно-тектонічними, літолого-петрографічними та геоморфологічними чинниками георізноманіття території та кількістю і якістю геологічних пам'яток природи тобто геосайтів. Доведена визначальна роль пам'яток природи у проблемі формування природно-заповідного фонду України та показана необхідність проведення моніторингу об'єктів геологічної спадщини. Надається порівняльний аналіз кількісної оцінки геологічної спадщини Дніпропетровської області, здійснений за різними джерелами та за різні роки. Акцентується увага на залученні геологічних пам'яток до використання у якості визначальних об'сктів геотуризму, а також на їх значенні, як головних компонентів майбутніх геопарків. На підставі моніторингу об'єктів геологічної спадщини, проведеного 32005 по 2015 роки, встановлені нові перспективні геосайти, перелік яких публікується вперше. Представлена коротка геологічна характеристика кожного нового геосайта, вказане його хроностратиграфічне положення та адміністративна прив'язка. Активна участь українських представників у роботі Європейської асоціації зі збереження геологічної спадщини (ПроГЕО), прагнення до створення Європейського ресстру геосайтів та усвідомлення необхідності збереження геологічної спадщини, дозволили вперше в історії руху за збереження навколишнього природного середовища розробити і впровадити у навчальний процес курс «Моніторинг об'єктів геологічної спадщини» для студентів які навчаються у галузі «Науки про Землю». У статті висвітлюється важлива роль практичної складової навчальної дисципліни, якою передбачені маршрутні польові геологічні дослідження студентів як під керівництвом викладача так і самостійні.
\end{abstract}

Ключові слова: геосайт, геологічна пам'ятка, ПроГЕО, моніторинг, геопарк, геотуризм, науки про Землю

Introduction. Dnipropetrovsk oblast is situated in the conjunction zone of three large tectonic structures: the Ukrainian Shield, the Dniprovsko-Donetska and Pry- chornomorska depressions. This is one of the main centers of concentration of significant mineral resources in Ukraine. Among them are the iron ore of the Kryvorizkyi 
and Kremenchutskyi basin, ilmenite ores of the Prydniprovska titanium-bearing zone (the largest such zone in the world), the Pavlohradske and Novomoskovske coal deposits, the gold deposits of the Surkske greenstone structure, the world's largest deposit of manganese in Nikopol, the Prosianivske kaolin deposit, the unique Tokivske and Kudashivske deposits of facing stone and many others (Manyuk, 2006). Near-surface position of Precambrian basal complex provides good opportunity to see and study its fragments in numerous natural and artificial outcrops. Apart from that, rock associations are characterized by significant variety lithological and petrological compound and large stratigraphic range of deposits - from Precambrian to quaternary deposits.

All of this together create an impressive potential collection of objects of geological heritage, which are characterized by the variety of types, high scientific value, and thus are worthy of inclusion in national and international registers. Natural monuments are one of key issues in nature conservation. They act as constant symbols, which form the images of natural landscape and nature of the Fatherland in the peoples ' conscience (Manyuk, Vad., Manyuk, Vol., 2012). Moreover, the geological monuments (geosites) are determinants of geological parks, the creation of which was first been the priority in Europe and subsequently became priority all around the world (Zouros, N., 2004, Manyuk, 2015). Parks which have already been created perform not only nature conservation functions, but are also important centers for the development of geotourism (Manyuk, 2008, 2014).

Presentation of the general material. It has been 10 years since the last revision study of Dnipropetrovsk oblast's geological heritage so the list of geosites has certainly undergone some changes. These changes are more significant than it may seem, even for such a relatively short period of time. The research on geological monuments that we conducted in 2004-2005 was due to realization of the idea of the State Service of Geology and Mineral Resources of Ukraine to republish the book "Geological Heritage of Ukraine" (Zarytskyi \& Shchyrytsa, 1985) and the idea of the Ukrainian group of the European Association for the Conservation of the Geological Heritage (ProGEO) to evaluate the potential of Ukrainian geosites and to create a data base necessary for participation in the international program GEOSITES (Wimbledon, 1997). The data base was created and the first variant is appropriate for selecting the most valuable objects of geological heritage for the European register of geosites despite certain disadvantages in the work conducted. According to the results of the revision study of geological relics a 4 volume study "Geological Landmarks of Ukraine" was published (Gurskyi \& Kalinin (eds.), 2011), but the problems of selecting the best geosites for the European list remains to be solved. But that is another story and a separate topic, the description of which is beyond the context of monitoring the geosites of Dnipropetrovsk oblast.

As of 01.01.2016 the official register of the oblast has 13 geological and two hydrogeological monuments. This can be enlarged by the addition of the landscape reserve of national value "Balka Pivnichna Chervona", a recently restored landscape reserve of local value "Domotkanski Valuny" and a regional landscape park Prydniprovskyi, which are geological in character (Manyuk, Vad.V., Manyuk, Vol.V., 2010, 2011). The guidebook "Geological Landmarks of Ukraine" provides information on 20 geological relics of Dnipropetrovsk oblast (Zarytskyi \& Shchyrytsa, 1985.). After the revision of study in 2004-2005, 42 geosites were identified, studied and recommended. 38 of them are included in the $2^{\text {nd }}$ volume of 4-volume edition "Geological Landmarks of Ukraine (Gurskyi \& Kalinin (eds.), 2011).

The activation of the movement for preserving geological heritage both at European and global level, participation of Ukrainian representatives of ProGEO in its international work, and the will to create a European register were a great impetus for the following work of geoconservation and its important component - geosites in many countries of the world. In particular, in 2013 in Dnipropetrovsk National University I introduced a new course "Monitoring the objects of geological heritage", aimed specifically at students majoring in "Geology", though the course is also recommended for all disciplines of natural studies (Manyuk, 2014, 2015). Using geological monuments for practical studies highlighted the necessity of undertaking a more detailed study of geological heritage, enlarging the list of potential geological monuments with the addition of new geosites and extending the possibilities of their usage. An especially significant aspect of popularizing geosites is using them as determinative objects of geotourism (Manyuk, 2015). The notion "geotourism" is relatively new, but using geological objects in the tourist sphere is rapidly gaining in popularity. According to the definition of Thomas Jose, who established this term in 1995, "geotourism is providing such educational base and services, which would give a tourist not only aesthetic impressions, but also understanding of geology and geomorphology of the place, including its role in the development of earth sciences (Ukrainian association of active and geotourism, 2016). Here we have one more important reason for evaluating the oblast's geosites by a further study of possible tourist routes and their usage. In the 
first variant a short characteristic of 19 objects of geological heritage is given.

1. The Dnipro rapids. The Dnipro river within Dnipropetrovsk oblast throughout its length cuts through the rocks of the Ukrainian crystalline shield, so it is understandable that this was the location of the majority of the Dnipro rapids. After the construction of the Dniprovska HES, the rapids were flooded with the water of the Dniprovske reservoir, but the banks of the Dnipro still feature giant massifs of granite, gneiss, migmatites and other Pre-Cambrian rocks.

Nature provides a great opportunity to see the oldest rocks, to study the variety of their petrotypes, tectonic structure, secondary processes of their changes and, finally, simply behold the beauty of landscapes which they create.

One of such areas with significant massifs of Dnipropetrovsk complex outcrops ( 3.2 billion years old) is situated between the villages Mayorka and Zvonetske. Rocky ledges of different shapes and size and of different petrographic compounds form an almost continuous line along the right bank. Here, there are mostly pink-greyish plagiogranites and migmatites formed by feldspar, quartz, biotite, and a small amount of accessory minerals. These rocks interweave veins and fibres of large reddish pink crystalline pegmatite, light pink small grade aplitic granites and epidosites, there are also dikes of greyish brown diabase.

2. Outcrops of Palaeogene and Neogene rocks in Skelka ravine.

Skelka ravine, which separates the right slope of the Byk river in the area of Slovianka village, in the low pre-river mouth part of its right slope, has a fairly large sand extraction quarry. Its length in amphitheatre is about $150 \mathrm{~m}$, the height of the practically vertical walls is up to $15 \mathrm{~m}$.

The walls of the quarry have outcrops of quaternary section fragment, Neogene and Paleogene deposits. The lower part has deposits of light-green glauconite-quartz small grade sands of late Paleogene Berekska suite (3-4 $\mathrm{m})$, above is erosion washout where they are blocked by sands and gravelite of Novopetrivska suite (from 3 to $8 \mathrm{~m}$ ) and loam of quaternary age $(0.5-4.5 \mathrm{~m})$.

The great value of the sands in the area was described by a famous researcher Valerian Domher - "The greatest thicknesses, in my opinion, are located between Novoandreevka and Iliashevka, especially in area of Lypko. Opposite Slavianka village, there is one such hill which is up to $10 \mathrm{~m}$; below it consists of sands of white, grey and greenish colors, and on the top, there is a layer of brownish-yellow sandstone up to 1.5 sazhen thick, which lies as a cornice...".
The section of the Novopetrivska suite has the highest scientific value. It is presented by typical deltaic facies, which are characterized by different types of cross-bedding, interbedding with gravel and coarse sand, and having processes of silicification with formation of grey quarzitic sandstone alternations. It is the sands of Novopetrivska rock formation, with which the best quarries of titan and zirconium in Ukraine are connected .

Slightly below the quarry, but on the slope of the Byk river ravine, there are large blocks of ochre-brown and reddish, very thick, quarzitic sandstone, exposed from sands of Novopetrivska rock formation due to processes on the slope.

\section{Petrivskyi quarry on the Byk with outcrops of Sarmatian rocks and Novopetrivska suite.}

A high ravine on the right slope of the Byk river near Petrivka village and near a picturesque bend of the river, has a sand pit, where a fragment of a typical section of Novopetrivska rock formation and Sarmatian rocks of the Neogene system was excavated. The quarry goes deeply into a high ledge as an amphitheatre with wall height of $15-20 \mathrm{~m}$.

The lower part of the section has an outcrop of varied thickness with alternation of light grey to white and yellow-grey fine-grained sand, quarzitic sands, which belong to middle Novopetrivska rock formation of Miocene subformation. Friable and quick sands cross-bed with clayey compressed sands of darker color.

The upper part of the section has thickness of alternation of light grey, grey and ochre yellow, medium quarzitic quick and imperceptibly clayey sands, which belong to the Volynskyi and Bessarabskyi substages of the Sarmatian stage of the Miocene section of the Neogene system. The rock's age is verified by finding fossilized Ostracoba and Foraminifers in it, which are typical of the Sarmatian stage.

4. Rocky outcrops of granites and migmatites along the Saksahan river between villages OrdoVasylivka and Marivka.

The area of the Saksahan river between villages Mahorta and Ordo-Vasylivka is beautified with numerous outcrops and migmatites, which tower above the river mostly along its right bank as separate rocky outcrops and groups of rocks, which create a picturesque landscape.

In age, the rocks belong mostly to the Demurynskyi complex of late Archean eon (2.965 billion years), which form the Demurynskyi granite-gneiss dome fold within the Serednoprydniprovskyi block of the Ukrainian shield, and which, along with granitoids of other complexes, form a matrix, which includes the Kryvorizko-Kremenchutska green stone structure with 
iron ore deposits. Apart from that, there are also small bodies of amphibole-black mica gneiss and migmatites of the Skeluvatska suite.

The petrology is characterised mostly by average crystalline plagiogranites and plagiomigmatite, often with a clearly seen injection- striped texture and with block-echelon rift, significantly smoothed processes of weathering and denudation. Most typical minerals are feldspars, quartz, biotite and amphibole.

5. Outcrops of granites and migmatites of the Dnipropetrovskyi complex in abandoned quarries in Tatarka ravine near Karnauhivka village.

Within the flood plain and first upper floodland terrace of the Tatarka river, the quarry works and also separate small rocky outcrops near Nadejdovka and Kamianuvata villages have exposed a fragment of section of plagiogranites and migmatites of the Dnipropetrovskyi complex of early Archean (3.2 billion years) eon. Migmatites have striped, spotted and plicate textures.

One of the two abandoned quarries is flooded and is used by the locals for leisure, and in the other quarry one can find the fullest and most varied number of crystalline rocks. The granitoid massif is broken by a system of differently oriented fissures, and the consequent processes of weathering and denudation have created differently shaped blocks.

Here, in the veins of aplite-pegmatoid granites, which cross the granitoid massif, epidote veins of 5 $\mathrm{cm}$ capacities were found. This is a beautiful mineral of bright light green color which belongs to the group of semi-precious stones.

6. Section of lake-glacier deposits in the mouth of the Kilchen river. Eurasia 's southernmost deposit of motley lake-glacier deposits of the Dniprovska ice age, were first identified in 2012 in the quarry to the north of Pidhorodne village (included in the city of Dnipropetrovsk). The roof has signs of Dniprovska moraine, blocked by Kodakskyi fossil soil, and in the base there is redish-brown Zavadivskyi fossil soil, which allows the climatic and stratigraphic position of Dniprovskyi climatolite to be accurately defined and allows the section to be recommended as an object of geological heritage of national value.

7. The outcrop of Dnipropetrovskyi complex granites in Osokorivtsa ravine. Along the thalweg and along the right slope of Osokorivka ravine, which is a right bank tributary of the Dnipro, near the south edge of Zelene village, the ravine`s erosion shows outcrops of crystalline Precambrian rocks. The rocks are a group of rocky outcrops, which tower above the thalweg of the river to 8-10 $\mathrm{m}$, have different shapes and are seen as a continuous line at a distance of about $100 \mathrm{~m}$.
Apart from angulated, echelon-block rocks, the upper part of the slope has peculiar round blocks, developed by the processes of weathering and rocks processed by glacier or round basalt lavas, though they have a completely different origin, which is connected with the deep metamorphism of the rocks and consequent weathering.

These rocks belong to the Dnipropetrovskyi complex of ultrametamorphic rocks of the early Archean period with an absolute age of 3.4 billion years. This complex is mostly located within the Serednoprydniprovskyi geoblock of the Ukrainian shield and significantly dominates among the rocks of other complexes. In petrographic compound, the complex is not uniform and the Osokorivka ravine's outcrop consists of diorite-alike grey-pink, average coarse plagiomigmatites, which are considered as products of granitization of the Slavhorodska rock mass and Oleksandrivskyi complex.

8. Hulaypolske metabasite outcrop near Malosofiivka village along the left slope of Bazavluk river.

To the north of Malosofivka village, the Bazavluk river flows into crystalline rocks of ChortomlytskoSolonivskyi green stone structure, forming picturesque rocky outcrops. There are outcrops of shists of quartzbiotite-amphibole Nyjnosurska subsuite $\left(\mathrm{AR}_{2} \mathrm{~s}_{1}\right)$ among plagiogranites and pegmatites of the Surskyi complex of the middle Archean ( $\mathrm{p} \mathrm{AR}_{2} s r$ ) with dikes of metapiroxenites of the Devladivskyi complex $\left(\sigma \mathrm{AR}_{2} d v\right)$ and dikes of diabases of late Archean $\left(\beta \mathrm{AR}_{3}\right)$. The Surska rock formation is presented by a lito-facial complex of meta-komatiite-tholeiite and shist-jaspilite-metatholeiite formation rocks. The formation consists of an association of amphibolites, amphibole-plagioclase shists (metabasalts), which cross-bed with talcum-carbonate, chlorite-olivine-serpentine rocks (peridotite metakomatiites) and chlorite-actinolite, tremolitic shists, actinolites.

9. Sandstone rock in Kryvyi Rih. Located on the right bank of the Inhulets river, $1.5 \mathrm{~km}$ to the south of a notable geological monument of local value "Outcrops of arkose sandstones", which is marked by a plaque horrible from a grammatical perspective, which says "an undressing of arkose sandstones". The outcrops of sandstones near the railway bridge and conveyer gallery of the Southern Mining and Enrichment Combine were omitted when both-the first and the second editions of the book "Geological Landmarks of Ukraine" were published. Anyway, this is quite a representative object of aesthetically attractive rocks, which consist of quartzitic meta sandstones of the Skelevatska rock formation of the Kryvorizka lower Proterozoic stage geoseries. The sandstones are one of the elements of a rhythmically composed conglomerate-sandstone-shist 
formation, which belongs to the eastern part of the main graben-syncline of the Krivbass.

10. Malomykolaivskyi quarry. In the east part of the oblast, to the west of Petropavlivka urbanized settlement, near the area where the Byk river flows into the Samara river, and near a small village Malomykolaivka, there is a sandpit, which has an exposed section of Neogene and Paleogene deposits. The vertical walls of the quarry, under a low capacity layer of eoliandeluvial Quaternary deposits, has outcrops of quartzitic white, yellow-grey and grey close sands (to aleurites) with lenses and interlayers of quartzitic sandstones and quartz of Novopetrivska suite of the Neogene, which lie on glauconite-quartzitic sands of Mejyhirska suite of Oligocene of Paleogene system.

11. Makhortynski plagiogranites and migmatites along the Saksahan river. In the area of the Saksahan river, mostly along its right shore, downstream from the Makhortynske water storage basin, in the area of Makhorta, Marivka and Ordo-Vasylivka villages, there are numerous outcrops of Precambrian crystalline rocksseparate rocks and groups of rocks, which beautify the landscape of the steppe river. Mostly they are leucocratic double-feldspatic, often gneissoid granites and migmatites of the Saksahanskyi complex of Upper Archean. Less common are the paliogranites and migmatites of the Saksahanskyi complex of upper Archean with remains of amphibolies of Bazavluk rock formation of middle Archean period. The processes of weathering and erosion of the river has created various shapes of rocky outcrops with niches, grottos, ledges, round formations.

12. Kamianskyi canyon in the Tokivski granites. Similarly to abovementioned "Sandstone rock" it has conservation status, but also was not included in the books "Geological Relics of Ukraine", which explains its inclusion in the up-dated list. $4.5 \mathrm{~km}$ below the locally famous Tokivskyi waterfall, the Kamianka river meets the granites of the Tokivskyi massif and creates one of the finest canyons of the oblast, whose walls are $20 \mathrm{~m}$ height. The Tokivskyi massif consists mostly of pink porphyraceous granites of massive uniform structure sometimes with not clearly distinguished fluidal arrangement of microcline porphyroblasts, and with a distinctive lilac color, which makes facing slabs cut out of the rocks especially valuable for the European market and home market. The Tokivskyi Late Archean granite complex, which forms the massif, belongs to the formation of after-folded allochthonous significantly microclinic granites with a clearly distinguished increase in alkalies in grano-syenite rock distinctions . Numerous vein bodies in the granites are formed by microcline, albite and plagioclase. There is also local greisenization, sulphidization and epidotization.

13. Chortiv zub. To the north of Kryvyi Rih, in Damanskyi microdistrict, is the famous Pryvorotna ravine. In the middle part of the ravine, a botanical garden is situated, and in the ravines mouth, erosion has exposed quite unusually shaped rocky outcrops of significantly altered, crushed cataclastic ultrabasic rocks. They are considered to be serpentized dunites, but this needs to be elaborated. The Saxon mining engineer Leo Shrippelman gave their description in 1872: "Granite-gneiss follows us to the ravine of the Pryvorotnye, which flows into the Saksahan on the right. After walking about 300 feet up the ravine, we will see definitely metamorphic, partly quartzitic and partly brecciform and conglomerate-type rock, which rises to the surface as a reef; its recesses and voids have probably developed after erosion of feldspar parts. Here, in disorder, mica, chlorous and clayey shists mix with deposits of limonite.

14. Quarry with outcrops of fluvioglacial deposits in Horoshevo village and outcrops of Sarmatian limestones with Solen and different Mollusca.

Along with the geological monuments "Suha Kalyna", which is located in the area near the mouth of the Vorona river, these are the northernmost outcrops of carbonate deposits of Sarmatian stage rocks of the Neogene system of the Cenozoic era. Here, one can find signs of the latest marine transgression into geological history, when the sea cut deep into the Ukrainian shield. Marlstone and limestone outcrops on the ravine's slope contain well preserved shells of different Mollusca, mostly Solen subfragilis (Eichw). Apart from that, in a small quarry near Horoshevo village, there is a section of Quaternary deposits with typical features of lake-glacier origin, which is unusual for the latitude. $36 \mathrm{~km}$ to the north, near Spaske village, we found the last signs of the Dniprovske glaciation (Manyuk, 2013).

15. The outcrop of Carboniferous sandstones on the right shore of the Byk river near Andronivka village. In the easternmost part of the oblast, between villages Andronivka in Mejivskyi district and Kamianka village, which is situated in Donetsk oblast, the only outcrop of Carboniferous System rocks in Dnipropetrovsk oblast is found. The walls of the quarry have outcrops of platy coarse dark-grey and brown-grey, weathered from the surface, often ferruginized quartzitic sandstone of Samarska suite of the Upper Carboniferous period. Sandstones contain inferior layers of thin platy aleurites and claystone.

19. Olenivsky quarry. In Krynychanskyi district, near Olenivka village, in a small abandoned quarry, there are Middle Prydniprovia outcrops very untypical 
for Precambrian formations: section of grey porphyroblastic, highly metasomatically altered granites with numerous schlierens, veins and apophyses of leucocratic pegmatoid granites. The rocks are characterized by a complicated composition of different bedding forms: vaults, spheres of different shapes and sizes, with intensively developed shelly jointing of desquamation origin. The void between the blocks is intensively filled with broken rocks with clear features of mylonitization, sericitization and epidotization. In differently orientated cracks, molybdenit is often found. Mica makes up 35\% of the rock (muscovite, sericite and biotite), quartz $30 \%$, plagioclase $-8 \%$ and microcline $-20 \%$. It is interesting that the sericitization pattern of slide, which is seen in metasomatically altered rhyodacites of green stone structures of Middle Prydniprovia, is connected by fault structures.

Conclusions. The peculiarities of the structure of Dnipropetrovsk oblast and the numerous outcrops of rocks of different ages have been described for the development of geotourism in the region and the use geological monuments for this purpose. Precise study of geosites, inclusion of new objects to the Nature Reserve Fund is also necessary for developing an ecological structure and preserving these areas both for those who appreciate them today and for future generations. An important aspect in studying and using the objects of geological heritage is involvement of future specialists of the sphere "Earth Sciences" as priority components in practical study.

\section{References}

Gurskyi, D.S., \& Kalinin V.I. (eds)., 2011. Geologichni pam'jatky Ukrai'ny. [Geological landmarks of Ukraine]. Kyiv, 2, 205-260 (in Ukrainian \& English).

Manyuk, V.V., 2004. Geological heritage of a southern part of Ukraine. Natural and Cultural landscapes. Proceedings of a conference, Dublin castle, Ireland, 93-98.

Manyuk, V.V., 2006. Stratigraphic control of distribution of useful minerals in the entrails of the earth of Dnipropetrovsk oblast. Bulletin DNU series: geology, geography. Dnepropetrovsk, 10(8), 10 - 15.

Manyuk, V.V., 2008. The problem of creation of a Network National Geoparks in Ukraine. Proceeding $33^{\text {th }}$ International Geological Congress, Norway, Oslo, 6-14 August.

Manyuk, V.V., 2013. Osoblyvosti budovy chetvertynnykh vidkladiv u typovykh rozrizakh Seredn'oho Prydniprovia. [Peculiarities of the building Quaternary sediments in typical sections of the Middle Dnieper]. Bulletin of Dnipropetrovsk National University, Series: geology, geography. Dnepropetrovsk, 21(1), 8 - 14.

Manyuk, V.V., 2014. Dosvid vyvchennya i vykorystannya heoturystychnykh ob'yektiv Seredn'oho Prydniprov'ya. [The experience of learning and using geotouristic objects of Middle Dnieper]. Geotourism: practice and experience. Proceedings of the International Conference. Lviv, SPC "Maps and atlases», 99-102 (in Ukrainian).

Manyuk, V.V., 2014. Novyy navchal'nyy kurs dlya studentiv heolohichnykh spetsial'nostey. [A new training course for students of grological specialties]. Mater. International science. conf. "The role of universities in development geology," Kyiv, 22-24 (in Ukrainian).

Manyuk, V., 2015. Objects of Geological Heritage in Kirovograd Region as a Basis for Development of Geotourism. International Materials of Science. Conf., 27-30 October. Kyiv: NHM of Ukraine, 146 - 149.

Manyuk, V.V., 2015. Geological Heritage and Geoscience education in Ukraine. Bulletin of Dnipropetrovsk University. Series: geology, geography. - Dnipropetrovsk, 23 (1), 17, 75 - 82. doi: 10.15421/111508.

Manyuk, V.V., 2015. Study and preservation of geosites: training course for geology students. In. Geoheritage 12371, Springer Berlin Heidelberg, doi 12371, 10.1007/s $12371-015-0147-$ y. -12 p. (on-line).

Manyuk, Vad.V., Manyuk, Vol.V., 2010. Pryrodno-zapovidnyy fond Dnipropetrovshchyny (stanom na 1 hrudnya 2010 roku). [Nature Reserve Land of Dnipropetrovsk (as of 1 December 2010)]. Training guide, Dnipropetrovsk, 90 -116 (in Ukrainian).

Manyuk, Vad.V., Manyuk, Vol.V., 2011. Pam'yatky pryrody Dnipropetrovs'koyi oblasti: navchal'nyy dovidnyk. [Natural monuments of Dnipropetrovsk region, training guide], Dnipropetrovsk, Royal Print, 38 - 53 (in Ukrainian).

Manyuk, Vad.V., Manyuk, Vol.V., 2012. Pam'iatky pryrody Stepovoho Podniprov'ia: istoriia, suchasnist ta perspektyvy. [History and culture Pridnieperovian: None known and little-known page]. Dnepropetrovsk: Nat. Mining University, 107 - 114 (in Ukrainian).

Ukrainian association of active and geotourism. Geotourism. Retrieved February 29, 2016 from http://uaeta.org/ua/ tourism $/ 24$.

Wimbledon, W.A.P. 1997. The former GILGES, and the new GEOSITES. Project of IUGS/UNESCO. In Look E.-R. (Ed.) Geotopschuttz und seine rechtlichen Grundlagen. Schriftenreihe der Deutschen Geologischen Gesellschaft. 5, 20-23.

Zarytskyi, A.Y., Shchyrytsa A.S., 1985. Geologicheskie pamjatniki Ukrainy. [Geological monuments of Ukraine]. Guide, Kyiv, Nauk. Dumka, 24 - 29 (in Russian).

Zouros, N., 2004. The European Geoparks Network Episodes. Greece, 27 (3), 165-171. 